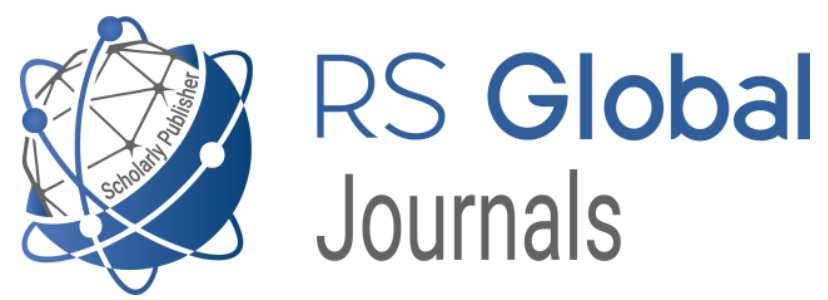

JOURNAL Science Review

p-ISSN 2544-9346

e-ISSN 2544-9443

PUBLISHER RS Global Sp. z O.O., Poland

ARTICLE TITLE OPERATIONS IN THE GEORGIAN OIL AND GAS INDUSTRY

AUTHOR(S) Archil Artmeladze

Archil Artmeladze. (2021) Improving the Management of

ARTICLE INFO Logistic Operations in the Georgian Oil and Gas Industry.

Science Review. 1(36).

doi: 10.31435/rsglobal_sr/30012021/7376

DOI https://doi.org/10.31435/rsglobal_sr/30012021/7376

RECEIVED 19 November 2020

ACCEPTED 10 January 2021

PUBLISHED $\quad 15$ January 2021

LICENSE This work is licensed under a Creative Commons Attribution

4.0 International License.

(C) The author(s) 2021. This publication is an open access article. 


\title{
IMPROVING THE MANAGEMENT OF LOGISTIC OPERATIONS IN THE GEORGIAN OIL AND GAS INDUSTRY
}

\author{
Archil Artmeladze, \\ Doctorate of Georgian Technical University, Batumi, Georgia
}

DOI: https://doi.org/10.31435/rsglobal_sr/30012021/7376

\begin{abstract}
ARTICLE INFO
Received 19 November 2020

Accepted 10 January 2021

Published 15 January 2021

\section{KEYWORDS}

ABSTRACT

In this paper is described the role and designation of logistics in oil and gas industry. Indicated specific factories which exist in the logistic system extraction of oil and gas, geologic exploration, and oil refinery. They must be taken into consideration in seeking the ways of raising the efficiency of logistic operations.
\end{abstract}

Logistic System, Oil and Gas

Extraction, Geologic

Exploration, Oil Refinery.

Citation: Archil Artmeladze. (2021) Improving the Management of Logistic Operations in the Georgian Oil and Gas Industry. Science Review. 1(36). doi: 10.31435/rsglobal_sr/30012021/7376

Copyright: (C) 2021 Archil Artmeladze. This is an open-access article distributed under the terms of the Creative Commons Attribution License (CC BY). The use, distribution or reproduction in other forums is permitted, provided the original author(s) or licensor are credited and that the original publication in this journal is cited, in accordance with accepted academic practice. No use, distribution or reproduction is permitted which does not comply with these terms.

According to the researchers, logistics is the management and control of material resources and / or the movement of goods related to them before, during and after production with proper information. The passage of these resources and goods into the various technical operations of production processes requires approximately $90 \%$ of all time costs. Therefore the use of a logistical approach should be aimed at reducing them. This reduction is carried out primarily between the purchase of raw materials and delivery of finished products to the consumer. Using a logistic approach, a reduction in the cost of goods is achieved by improving the quality of supply and increasing reliability. The movement of material flows takes place according to the following scheme "supply-production-distribution-consumption", which allows the whole production cycle to be considered in a single section and is called the logistics system. The logistics system includes the entry or acquisition of various subsystems - material flows, a warehouse, where material supplies are temporarily stored, which is then transformed into a material stream to transport, transport cargo, information that provides connections between elements of the logistics system and facilitates the efficient operation of logistics operations.

The logistics system is characterized by integration. which does not have a separate his element. This ability ensures the delivery of the required goods at the required time to the required quantity and quality on the spot, with minimal losses and adaptation to environmental conditions Thus, logistics involves a comprehensive approach to identifying costs and reducing them in all areas - from material supply to distribution [1].

The goal of industrial logistics is to manage the production process and logistics operations with precise synchronization without excess supplies; Spending little time on major and transportwarehousing operations; Production only of products or parts in demand; Inadmissibility of device attempts; Definitely eliminate rot; Avoiding irrational inland shipments; Turn suppliers into benevolent partners or improving compliance and enhancing suppliers corroborations. 
Logistics activities in Georgian oil and gas enterprises have specifics, which are accompanied by some problems, namely oil losses from extraction from wells to oil companies $-4 \%$, oil transportation and storage in oil depots $-3 \%$, oil refineries $-3 \%$. In addition, 50 to $80 \%$ of the oil reserves remain untouched in the entrails. Losses are significant in the extraction of natural and follower (petroleum) gas - both during processing and consumption.

Nearly $30 \%$ of material and technical resources in oil extraction are occupied by auxiliary materials (well pumps, belts, ropes, demulsifiers, black and colored materials, raw materials, etc.) Auxiliary materials for gas extraction and spare parts for inventory and fixed capital repairs, are $-35 \%$ in the gas sector.

Characteristic in the drilling of oil and gas wells is that almost $60 \%$ of working capital comes from small and fast-moving items. This is due to the fact that a large number of expensive and non-long-term tools are used for the construction of mining wells - drill pipes, extenders, saws, wrenches, saw ropes, etc. In addition, drilling requires a larger amount of material supplies than other enterprises in the field.

The oil and gas industry does not require raw materials as a material resource for the technological process. The raw material for it is in the ground or on the surface of the land within the license block in the form of mineral resources or reserves. With the training of geologists, these resources are then transferred to reserves Therefore, mineral reserves must be differentiated from the material resources, that the enterprise receives from the supplier.

Mineral resources for the oil and gas industry are endowed by nature. In this sector we also do not find semi-finished products and unfinished production in the form of costs. The latter can be encountered in drilling wells.

Any enterprise, including oil and gas production, stores the material resources ordered and received for normal activities in the form of various supplies in the warehouses. But when we are talking about mineral reserves, these reserves are "stored" in the earth's crust or on its surface and are the subject of geological research.

Working capital may be present in the production process when, according to the technological cycle, they have already changed their form, but no new products have been received yet. The demand for material and financial resources that ensure the normal conduct of the entire technological cycle from its inception to the receipt of the finished product is called "unfinished production". Unfinished production of geological exploration works - this is done. But unpaid works as defined by the geological assignment (or its stage).

"Unfinished production" in geological exploration works differs somewhat from its economic importance in other fields. The term of the geological task can be extended for several years, so the remuneration of the work according to the final result requires a large amount of funds to provide work at the stage of "unfinished production". In order to accelerate the financial movement, the works of the geological assignment shall be reimbursed once a month in accordance with the performance of the works. But even such intermediate reimbursement of works leads to the point that "the time of unfinished production is 30-35 days. This means that the geological prospecting organization must have sufficient cash during this time. In some industries this time is 1-2 days, while in electricity there is no 'unfinished production' at all.

In industries such as construction and mining, there is a need for significant material and financial resources to provide only future production. For example, quarrying during ore processing, environmental measures and so on

The logistics system of all blocks of oil supply creates a comparative advantage, which allows to produce complex hydrocarbons at relatively low alternative costs, thus increasing the sector's export and production capacity. The logistics of an oil and gas plant involves the management and design of production resource flows when extracting hydrocarbons within the company's internal environment.

In the supply of goods to oil and gas companies in the sector, oil and gas go through purchasing channels, export and domestic consumption. It eventually becomes a common element in the user system. Due to the integrative nature of logistics functions, oil and gas enterprises can reduce the costs of providing material and technical services up to $9 \%$ of the offered price, and when selling products for export - by $20 \%$. Thus, it is necessary to use a logistical approach to create a complex system of production resource management and control over oil and gas facilities.

After the introduction of Georgian oil and gas regulatory legislation in the second half of the 1990s, favorable preconditions were created for the entry of new investors into the fields and the 
introduction of modern mineral extraction technologies in the existing fields, which was reflected in the increase current oil extraction .However, as it turned out, the contractors, with a few exceptions, focused on exploiting existing stockpiles and paid inadequate attention to exploration to find new deposits, which led to a decline in oil production after 2004.[2]

It is planned to make relatively high investments in oil exploration and extraction works in the coming years. The main focus of the activity is shifted to intensive seismic exploration in the country and the discovery of new deposits in exploration drilling, and to increase oil extraction in existing deposits. Experts estimate that oil production may increase in the near future, if the forecast resource indicators of at least one of the prospective fields are confirmed.

Since the early 2000s, oil and gas exploration and production have been revived and increased as a result of the activities of 12 foreign companies employed in the sector. The total volume of seismic surveys conducted during this period is two-dimensional 2D-6100 km and three-dimensional works $1745 \mathrm{~km} 2$. Up to 30 deep and up to 50 shallow exploration and exploration wells were drilled. About 40 promising structures have been identified, including in the Georgian part of the Black Sea. Drilling on four of these structures has already confirmed the presence of hydrocarbons in the Middle Eocene and Upper Cretaceous sediments. Although their commercial importance can be determined by further drilling. Although no new commercially interesting deposits have been discovered during this period, recent work suggests that new commercially interesting deposits will inevitably be discovered. Currently, a total of 16 industrial deposits have been discovered in the country. 5 new deposits have been identified, on which the existence of supplies of industrial importance for various reasons has not yet been finally confirmed.

Table 1. The oil and gas reserves and resources for January 1, 2020 are as follows: (Figures taken from the Georgian State Oil and Gas Agency)

\begin{tabular}{|c|c|c|c|c|}
\hline & category & Oil (mln.t.) & $\begin{array}{l}\text { Petroleum gas } \\
\left(\mathbf{m l n} \cdot \mathbf{m}^{3}\right)\end{array}$ & $\begin{array}{c}\text { Natural } \\
\left.\text { gas(mln.m }{ }^{3}\right)\end{array}$ \\
\hline \multirow{3}{*}{ reserves } & 1P & 3,162 & 149,258 & 3742,560 \\
\hline & $2 \mathbf{P}$ & 7,831 & 422,296 & 4874,830 \\
\hline & $3 \mathbf{P}$ & 41,059 & 952,761 & 6153,880 \\
\hline \multirow{3}{*}{$\begin{array}{l}\text { contingent } \\
\text { resources }\end{array}$} & $1 \mathrm{C}$ & 32,968 & 3207,470 & 7,8 \\
\hline & $2 \mathrm{C}$ & 81,260 & 8203,160 & 13,4 \\
\hline & $3 \mathrm{C}$ & 203,570 & 22057,180 & 20,4 \\
\hline \multirow{3}{*}{$\begin{array}{l}\text { prospective } \\
\text { resources }\end{array}$} & $\mathbf{L}$ & 99,274 & 40001,500 & 86301,420 \\
\hline & $\mathbf{M}(\mathbf{B})$ & 601,086 & 13742,0 & 208238,261 \\
\hline & H & 4000,457 & 32332,3 & 312095,130 \\
\hline
\end{tabular}

The peak of natural gas production (free and flowing) was observed in 1983 (approximately 333 million cubic meters) coinciding with the intensive period of oil, but the subsequent decline in oil production led to a significant decline in gas production by 2020 .

In August 1974, the Samgori-Patardzeul-Ninotsminda field was opened in the Tbilisi region, as a result of which oil production increased dramatically from 22 thousand tons in 1973 to 1751 thousand tons in 1977. Accordingly, in order to optimize the costs for the initial oil production, it was decided to build a main building for the collection and preparation of light in the field 4 million tn. with an annual output that went into full force in 1978. According to the project, it envisages the production of products from wells through underground pipelines, primarily through a two-stage separation cycle. The gas obtained for the separation of the accompanying gas from the oil is supplied to the customer through the compressor units through a $33 \mathrm{~km}$ long gas pipeline with a diameter of $530 \mathrm{~mm}$. In 1980-83, the volume of gas supplied to the Gardabani thermal power plant was 1 million cubic meters per day. [2] 
The commodity oil obtained as a result of the primary processing will be transferred to the Georgian Main Oil Pipeline Company, which owned 2 commodity oil reservoirs with a capacity of $10,000 \mathrm{~m}^{3}$ and a pumping station. This station provided pumping of oil to the former oil refinery in Batumi. The length of the Batumi-Samgori pipeline was $400 \mathrm{~km}$, in diameter - $530 \mathrm{~mm}$, plant's annual capacity-5million tons.

Gas separation from liquefied petroleum products and liquefied petroleum gas fractions are measured on group measuring devices, from which the products of the oil-water compound - "fluid" are supplied to the main building by tankers. The resulting fluid will be loaded into the receiving reservoirs where free water is diverted. For further preparation of the product by means of a pump, with the addition of a demulsifier, it is supplied to the heating furnace, and then stored in the technological equipment for the preparation of commodity oil. Commodity oil is collected in one of the 50,000 cubic meter reservoirs, from where pumps are supplied to one of the 1,000-cubic meter reservoirs. From the latter, oil is delivered to an off-site delivery point, where it is loaded into tankers.

Currently, there are two small-capacity oil refineries in Georgia with a total production capacity of 210 thousand tons. Relevant analysis confirms that the quality of their products is in full compliance with the requirements of current standards in the country.

It should be noted that in the period from 1995 to 2020, about one billion US dollars were invested in the oil and gas sector of Georgia.

According to experts, as a rule, the share of logistics system implementation costs is $38-40 \%$ of the investments made. Therefore, in order to increase production efficiency, it is necessary to increase hydrocarbon extraction at the expense of the detection and commissioning of new deposits and to improve the operations of the logistics system.

\section{REFERENCES}

1. The logistic role in development of Georgian economy www.gla.ge/wiew supply-chain.org

2. T. Gochitasvili, S. Gudushauri-Oil-and Gas bearing Potential and Trunk Pipelines of Georgia. Tbilisi, 2019. 262p.

3. Shota Veshapidze, D. Osadze, D. Sexniasvili Logistic Tbilisi, 2012

4. Roman Mamuladze Meri gabaidze. Logistic Batumi. 2013, 523p. 